\title{
Univ. of Georgia
}

Final Technical Report for DOE Award No. DE-FG02-97ER20258

Title: Plant Cell Wall Architecture

Funding period: 04/01/97 to 03/31/99

Award amount: $\$ 73,687$

The goals of the funded project were to investigate the roles of caffeoyl coenzyme A $O$-methyltransferase (CCoAOMT), an enzyme involved in the phenylpropanoid biosynthetic pathway, in the biosynthesis of lignin. We proposed to analyze the expression patterns of CCoAOMT in plants, and examine how reduction in the expression of CCOAOMT would affect lignin content and composition. With the financial support of this project from DOE, we had successfully fulfilled our goals and made significant findings on lignin biochemistry. As a result, two papers describing our findings were published in plant journals of the highest quality, and one U.S. patent application based on our findings was filed. A brief summary of our findings follows.

1) We previously found that CCOAOMT was associated with lignification in both in vitro tracheary elements (TEs) and organs of zinnia. To know whether this is a general pattern in dicot plants, we examined the expression of CCoAOMT in dicot plants including forsythia, tobacco, tomato, alfalfa, and soybean. CCoAOMT was found to be localized in all lignifying tissues, including TEs, xylem fibers, phloem fibers, and xylem ray parenchyma cells. This finding supports the hypothesis that the CCoAOMT-mediated methylation pathway is a general one in lignin biosynthesis during normal growth and development in dicot plants. A paper on this finding was published in Plant Physiology (1997, 115: 1341-1350).

2) To investigate whether CCoAOMT is essential for lignin biosynthesis, we used an antisense approach to alter CCOAOMT gene expression and examined the consequences of this alteration. We found that the reduction in CCoAOMT resulted in a dramatic decrease in lignin content as well a dramatic alteration in lignin composition. We have also analyzed lignin content and composition in transgenic plants having a simultaneous reduction in both CCoAOMT and caffeic acid $O$ methyltransferase (COMT). The reduction in both $O$-methyltransferases resulted in a further decrease in total lignin content. These new findings unequivocally, for the first time, demonstrate that methylation reactions in lignin biosynthesis are catalyzed by both CCOAOMT and COMT. A paper on this finding was published in Plant Cell (1998, 10: 2033-2045).

3) The demonstration of the essential roles of CCoAOMT in lignification has not only enriched our knowledge of the lignin biosynthetic pathway but also implies the potential utility of CCOAOMT as a target for genetic engineering of lignin. A US patent application was filed based on the findings described above (U.S. Patent Application Serial No. 09/453,323; DOE Case No. S-91,687).

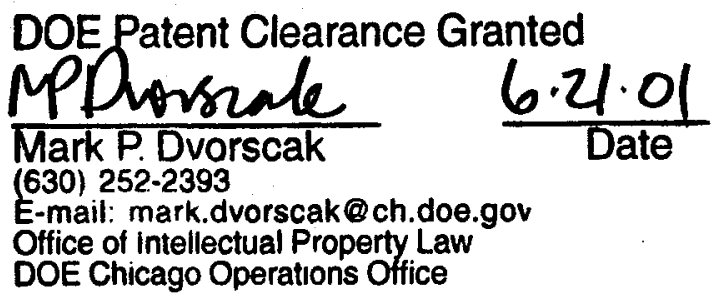




\section{DISCLAIMER}

This report was prepared as an account of work sponsored by an agency of the United States Government. Neither the United States Government nor any agency thereof, nor any of their employees, makes any warranty, express or implied, or assumes any legal liability or responsibility for the accuracy, completeness, or usefulness of any information, apparatus, product, or process disclosed, or represents that its use would not infringe privately owned rights. Reference herein 10 any specific commercial product, process, or service by trade name, trademark, manufacturer, or otherwise does not necessarily constitute or imply its endorsement, recommendation, or favoring by the United States Government or any agency thereof. The views and opinions of authors expressed herein do not necessarily state or reflect those of the United States Government or any agency thereof. 


\section{DISCLAIMER}

Portions of this document may be illegible in electronic image products. Images are produced from the best available original document. 